\title{
Drone Functional Service System for Dementia Seniors in the Aging Society towards the Innovative Safe Welfare Hyojin Choi ${ }^{1}$;Serim Byeon ${ }^{2}$; Youngsin $\mathrm{Lee}^{3}$; Suyeon Kim ${ }^{4}$; Yoo- Jin Moon ${ }^{5 *}$
}

Division of Global Business \& Tech., Hankuk Univ. of Foreign Studies,South Korea ${ }^{12345}$

chj7960@naver.com ${ }^{1}$; serim3464@gmail.com ${ }^{2}$; lys1798@naver.com ${ }^{3}$; aab981030@naver.com ${ }^{4}$; yjmoon@hufs.ac.kr ${ }^{5 *}$ - corresponding author

DOI $10.26821 /$ IJSHRE.8.7.2020.8705>

\begin{abstract}
The paper proposes the drone functional welfare service system for the dementia seniors and their protectors utilizing drones and big data in South Korea, which has entered an aged society at a rapid pace. To solve the problems of dementia seniors being exposed to danger and protectors with increased stress, it recommends that devices identify the real-time location of the dementia senior and the protectors and that the police station provide services that enable the drone to be dispatched and situation-sharing if desired. Based on the statistics of police stations and the data of senior citizens in Seoul Metropolitan Area, it automatically analyzes the possibility of drones appearing when the senior is out and comes within the danger zone radius. The research may contribute to the nation for providing dementia seniors with reducing the missing probability and for providing their protectors with more personal social works and leisure in an aged society, and for increasing the performance efficiency of police administrations. Furthermore, the proposed solutions will expand the scope of the target with safety services to socially disadvantaged people such as children, the seniors and the disabled, which will increase the overall effectiveness of the social safety.
\end{abstract}

Keywords: Dementia Senior, Aged Society, Welfare, Real-Time Location, Drones

Hyojin Choi;Serim Byeon; Youngsin Lee; Suyeon Kim; Yoo-Jin Moon, Vol 8 Issue 7, pp 34-42, July 2020

\section{INTRODUCTION}

Dementia is a comprehensive term that refers to a state in which memory-oriented cognitive impairment caused by brain damage hinders one from maintainingthe previous level of daily life [1]. Also, it creates a complex symptom in which the normally mature brain is damaged or destroyed by a foreign person, e.g.acquired trauma or disease, which generally reduces one's intelligence and cognitive and mental functions.

Currently, there are 50 million dementia seniors worldwide and the number is expected to triple to 150 million by 2050 . The number of dementia people in South Korea is gradually growing with 750,000 in Figure 1, far more than the Jeju provincial government's population with around690,000 [2].Dementia seniors are exposed to dangerous situations such as walking outside of their home alone when their protectors cannot take care of them [3]. 


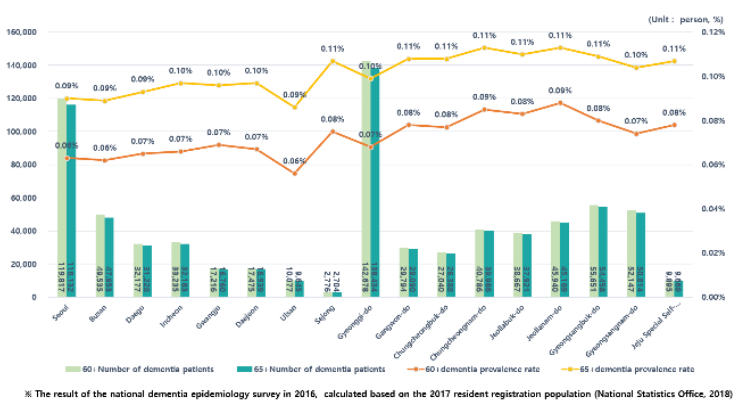

Fig1: Domestic dementia population [4]

Currently, there are 1.8 dementia-related seniors per100 working age populationwhich correlates to 1 dementia senior per 56.4 working age population. One can see that South Korea's burden relating to dementia seniorsis high. People in their 50s or older consider dementia as the most fearfuldisease, and thus have high psychological anxiety towards dementia $[4,5]$.

The number onepriority for the seniorwith dementia is going outside safely. In addition, the burden of care for the dementia seniorbringsincreased stress for protectorsas in Figure 2.

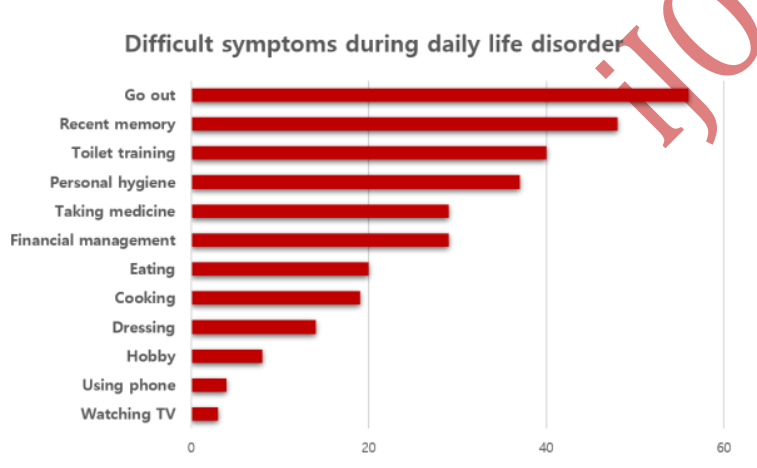

Fig 2: Difficulties of the dementia seniors experienced by their protectors

Because of these reasons, dementia seniors need services that ensures them to go outside safely without the need of protectors [6].

With the recent signing of a business agreement between KT and Hwaseong City, a control system utilizing drone services is being established to monitor crime areas and seniors from safely returning home [7].In addition, a British company has released drone services that escort customers back to home at night [8].More and more drones are being used for safety purposes. The drones supplementthe policing work by providing real-time footage which helps the police to prevent subsequent accidents from happening. .

Therefore, the reasons why the researchchoose the Drone Functional Services for seniors with Dementia as the topicare as follows.

First, dementia seniors should be protected from everyday danger. The location and appearance of dementia seniors should be checked quickly to protect them from falling into dangerous or accidentprone areas $[9,10]$.

Second, the stress that the protectors receive from taking care of dementia seniors should be reduced. Protectorscannot take care of dementia seniors for 24 hours, so they should be able to use location-based services by utilizing drones to check the seniors'location and appearance from a distance.

Third, thedemand for services based on safety and trust are high. The drone service utilizes data values as a basis which is stored by the police to ensure trust and safety of the users [11].

For the above reasons, the database system utilizing the drones with location-based servicesis suggestedfor the dementia seniors. This systemcan be used as a safety service that connects vulnerable groups, their protectors and police departments together.

\section{RELATED STUDIES AND BIG DATA SOURCES}

'A Study on the Organizational Operation of the Security Drone Patrol' says that the base-style security drone patrols should increase the effectiveness of responding to various police complaints and preventingcrimes [12]. With the government's push for the innovative drone industry and growing interest from the private sector, more and more institutions are using drones. Areas of the security service that utilizes drones have also been increasing continuously. In order to establish a social safety net which includes searching missing persons, the National Police Drone Association organized a national police detachment of more than 1,000 drone police officers nationwide, which shows that the potentialof using security drones is high. In addition, in order to effectively operate the division of police work at police stations in the district against the increasing number of emergency calls by residents, the government should establish a drone patrol 
system that includes advanced security drone patrols and emergency call reception system. Also, this will have great savings in the police work in the aspects of police personnel and budget.

The researches [12, 13, 14, 15] prove the feasibility and efficiency of using drones. The drones have been distributed to local police stations and hospitals, which iseffective for safety of vulnerable people,budget saving and efficiency of police work.Thus, they already have police and hospital personnel who can operate drones.

The researchis different from the previous studiesin that it targets the dementia seniors. The ultimate aim of the researchis toprovide the effectiveness for the dementia seniors and expand the scope to children, the senior,women and the weak.

The sources of big data used for the researchare as follows.

First, the research usesthe Seoul Metropolitan Government statistics on welfare facilities for the seniors inJungrang-gu, Gangseo-gu, and Yeongdeungpo-gu, which have the most senior welfare facilities in Korea.

Second, the dwellings in the above three districts are selected from the map to enter the latitude and longitude of the seniors' residence. Similarly, streets and buildings within the three districts areselected to enter the real-time latitude and longitude of the seniors.

Third, sex offender notification websites and TAAS traffic safety mapsare used for open data in dangerous areas [16, 17]. The latitudes and longitudes of sex offenders living in the three districts are entered. The TAAS traffic safety map identifies the location of the pedestrian accident area and enters the latitude and longitude of the area.

Fourth, locations of the district, police stations and security centers located in three districts areconfirmed through the Seoul Metropolitan Police Agency's information on the police station's data [18]. Five police stations located in the east, west, south, north and center of the district are chosen and their latitudes and longitudes are entered as data values.

The above four data set are used to organize the data for this researchand produce useful results.

\section{SYSTEM ARCHITECHURE}

\subsection{Entity-Relation(E-R) Diagram}

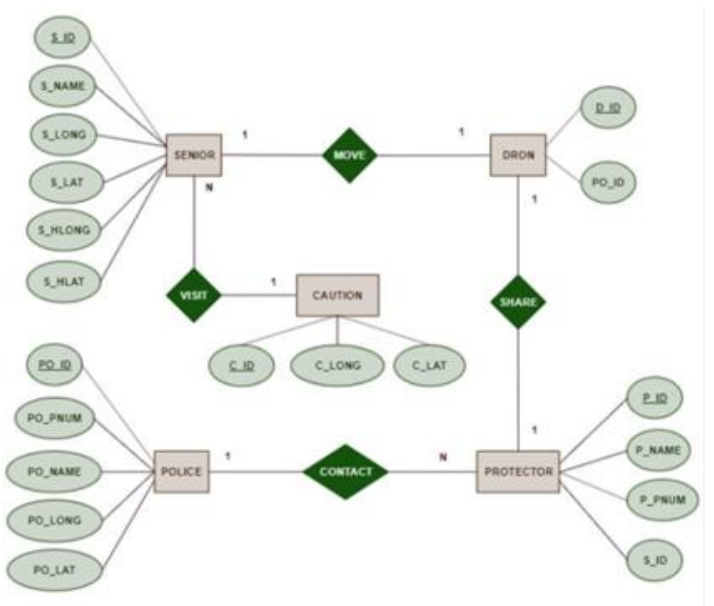

Fig 3: E-R Diagram for Drone Functional Service

The composition of the E-R diagram of the drone service database systemis shown in Figure 3.

The E-R diagram expresses the movement relationship of the drone and dementia senior entity, the contact relationship between police and protectors, the sharing relationship between drones and protectors and the visiting relationship between the senior and dangerous areas.

The SENIOR entity hassix attributes., which consists ofthe senior id (S_ID), the name of the senior (S_NAME), the real-time senior latitude (S_LAT), real-time senior longitude(S_LONG), and the latitude (S_HLAT) and the longitude (S_HLONG) which represent the location of the house in which the senior reside.

The drone (DRONE) entity has two attributes, which are the drone number (D_ID) expressing the unique number assigned to one droneand the police station number (PO_ID) to which the drone belongs.

The guardian (PROTECTOR) entity hasfour attributes, which consist of a protector number (P_ID), a protector name (P_NAME), a protector's cell phone number (P_PNUM), and a senior number (S_ID) that the protector wants to protect.

The police (POLICE) entity hasfive attributes, which consist of the unique number (PO_ID) assigned to the police station, the police office number (PO_PNUM), the name of the police station (PO_NAME), and the latitude (PO_LAT) and longitude (PO_LONG) of the location of the police station. 
Volume 8 Issue 7 July 2020

Finally, a CAUTION entity indicatesa hazardous area. The Hazard zone entity consists of three attributes, which are the hazard zones number (C_ID), the location of the hazard zone latitude (C_LAT), and the hazard zone longitude (C_LONG).

\subsection{Description of Schema and Relations}

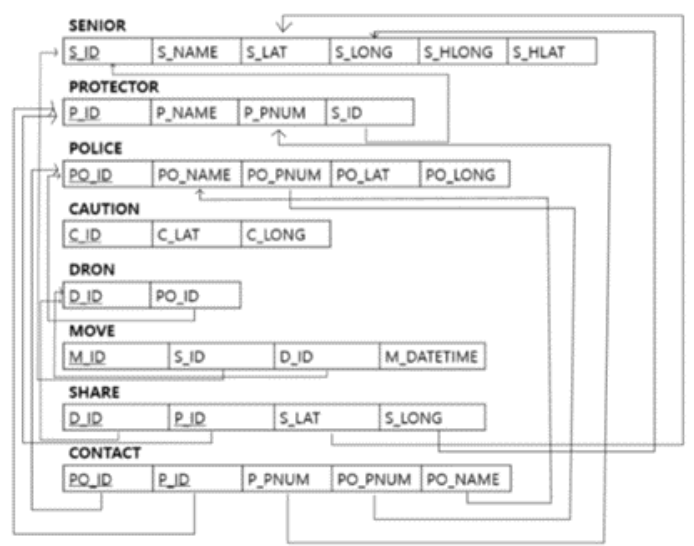

Fig 4: Database schema

The database schema configured based on the E-R diagram ofFigure 3 is shown in Figure 4 . The primary key of each table is underlined;the foreign key points to the attributes of the table to which the arrow points; the starting point of the arrow is the property of the table to which the foreign key belongs.

There are S_ID, S_NAME, S_LOG, S_LAT, S_HLONG, S_HLAT attributes in the SENIOR table, and the primary key of SENIOR is the senior number (S_ID).

The PROTECTOR table has P_ID, P_NAME, P_PNUM, S_ID attributes and the primary key is P_ID. In addition, the senior number (S_ID) is foreign key, referring to the S_ID attribute on the SENIOR table.

The POLICE table contains the attributes PO_ID, PO_PNUM, PO_NAME, PO_LAT, PO_LONG and the primary key is the police station number (PO_ID).

The CAUTION table has C_ID, C_LAT, C_LONG attributes and the primary key is dangerous area Number (C_ID).

The DRONE table has D_ID, PO_ID attributes and the primary key is D_ID. In addition, the police station number (PO_ID) to which the drone belongs was used as foreign key referring to the police station number (PO_ID) on the police table.

Out ofthe four relationships in the E-R diagram, three(MOVE, SHARE, CONTACT) were expressed as a schema.

The MOVE relationhas a moving number (M_ID) attribute; every time a drone is sent to a senior, it gives the movement of another drone and a new number that can be identified. In addition, there are S_ID and D_ID attributes that are moving along with the senior. And it consists of a date time attribute (M_DATAETIME) that indicates the date and time when the movement occurred. The primary key of the MOVE relation is M_ID, and the senior number and the drone number are entered as foreign keys.

The SHARE relationexpresses the situation sharing to the protector and shows the real-time latitude (S_LAT), real-time longitude (S_LONG) of the senior. All these attributes are foreign keys, which are organized by reference to the attributes of other tables. Refer to the D_ID of the drone table, the P_PNUM of the protector table, and the S_LAT, S_LONG property of the senior table, respectively. The primary key consists of Drone Number (D_ID) and Protector Number (P_ID).

The CONTACT relation expresses the contact between the protector and the police station. It consists of the attributes of the police station number (PO_ID), protector number (P_ID), protector's phone number (P_PNUM), police station office number (PO_PNUM), and police station name (PO_NAME). The CONTACT relation, as well asthe SHARE relation, consists of all foreign keys. Refer to PO_ID, PO_PNUM, PO_NAME on the POLICEtable and P_ID, P_PNUM on the PROTECTOR table respectively.

The relational tables do not save the data separately because they can implement the results in SQL syntax when they produce useful results for the research. The results of each SQL statement will be stored on each relational table when it is linked to the app in the future.

\section{REPRESENTATIVES OF USEFUL INFORMATION}

The main services provided by the drone service database system are as follows:

First, it automatically sends a notification to the protector when the dementia senior goes out. The 
Volume 8 Issue 7 July 2020

protector can see that the senior was out of the house by looking at the notice.

Second, it usually guides to a police station near its current location only if the protector wants to share the situation, and then the protector can ask the police station to move the drone.

Third, when the dementia senior enters within the hazard zone, an automatic notification is given to the protector and the police station, and drones are automatically moved from the police station close to the current location.

The useful information required to provide these services is as follows:

\subsection{Notification of \\ theDementia'sGoingOut}

The tables used in this query are SENIOR andPROTECTOR tables. The fact that the dementia senior goes out means that the real-time location is different from that of his/her home. Therefore, the condition is set to be the case where the longitudes of the real-time position (S_LONG) and the house (S_HLONG) are different, and where the latitudes of the real-time position (S_LAT) and the house (S_HLAT) are different. The real-time location of the senior is the latitude and longitude values measured under the assumption that the senior is wearing a GPS bracelet.

If the dementia senior goes out, the name of senior (S_NAME), the name of the protector (P_NAME), and the protector's phone number (P_PNUM) are printed without any duplication. Through this SQL statement, when a dementia senior is out the service can send an alert to his or her protector's cell phone.

The results of the above query are shown in Table 1 .

Table 1.Notification Results of the Dementia's Going Our

\begin{tabular}{|c|c|c|}
\hline S_NAME & P_NAME & P_Pnum \\
\hline Park Yeongja & Park Jeonga & $\begin{array}{l}010-0768- \\
1674\end{array}$ \\
\hline Park Jeongja & Park Hyeongseo & $\begin{array}{l}\text { 010-0100- } \\
9955\end{array}$ \\
\hline Park & Park & 010-0267- \\
\hline Sunjeong & Hyeonseong & 7723 \\
\hline Park Chunja & Park Jinho & $\begin{array}{l}010-0333- \\
0447\end{array}$ \\
\hline $\begin{array}{l}\text { Park } \\
\text { Gyeongja }\end{array}$ & Park Jeonghwan & $\begin{array}{l}010-0062- \\
2105\end{array}$ \\
\hline
\end{tabular}

\begin{tabular}{|c|c|c|}
\hline Park Okja & Park Hanseo & $\begin{array}{l}010-0298- \\
7991\end{array}$ \\
\hline $\begin{array}{l}\text { Park } \\
\text { Myeongja }\end{array}$ & Park Mina & $\begin{array}{l}010-0845- \\
2002\end{array}$ \\
\hline Park Hwaja & Lee Eunji & $\begin{array}{l}\text { 010-0232- } \\
0951\end{array}$ \\
\hline $\begin{array}{l}\text { Park } \\
\text { Yeongmi }\end{array}$ & Lee Jihyeon & $\begin{array}{l}010-0334- \\
0592\end{array}$ \\
\hline $\begin{array}{l}\text { Park } \\
\text { Miyeong }\end{array}$ & Lee Seohyeon & $\begin{array}{l}010-0274- \\
4344\end{array}$ \\
\hline
\end{tabular}

\subsection{Notification of the}

\section{Dementia'sEnteringthe Hazard Zone}

The tables used in this query are SENIOR, CAUTION, andPROTECTOR tables.

The hazard zoneis set at 50 meters from the dangerous areasuch as senior citizens' traffic accident-prone areas andthe residential areas of sex offenders. Sincea 50-meter differs by about 0.002 when converted to latitude and longitude, the condition is set to be between the real-time position of the senior and the hazard zone \pm 0.002 .

If the conditions are met, the senior name (S_NAME), the protector name (P_NAME), and the protector phone number (P_PNUM) can be printed to automatically notify to the protector that the senior has entered the hazard zone.The results of the above query are shown inTable 2.

\section{Table 2.Notification Results of the Dementia's Entering the Hazard Zone}

\begin{tabular}{|c|c|c|c|}
\hline S_ID & S_Name & P_Name & P_Pnum \\
\hline s002 & $\begin{array}{l}\text { Kim } \\
\text { Sunjeong }\end{array}$ & Kim Suyeon & $\begin{array}{l}010-0042- \\
7880\end{array}$ \\
\hline s003 & $\begin{array}{l}\text { Kim } \\
\text { Chunbae }\end{array}$ & Lee Yeongsin & $\begin{array}{l}\text { 010-0414- } \\
0200\end{array}$ \\
\hline s005 & $\begin{array}{l}\text { Kim } \\
\text { Migyeong } \\
\end{array}$ & Kim Eunji & $\begin{array}{l}010-0750- \\
1845\end{array}$ \\
\hline s011 & Kim Hwaja & $\begin{array}{l}\text { Kim } \\
\text { Hyeonseong }\end{array}$ & $\begin{array}{l}\text { 010-0608- } \\
0587\end{array}$ \\
\hline s044 & Lee Mijeong & $\begin{array}{l}\text { Choi } \\
\text { Hyeonseong }\end{array}$ & $\begin{array}{l}010-0317- \\
9929\end{array}$ \\
\hline s045 & $\begin{array}{l}\text { Lee } \\
\text { Miyeong }\end{array}$ & Choi Jinho & $\begin{array}{l}010-0647- \\
4417 \\
\end{array}$ \\
\hline s078 & BaekSunja & Song Yeonsu & $\begin{array}{l}010-5400- \\
9159\end{array}$ \\
\hline s079 & BaekJeongsu & Song Eunseo & $\begin{array}{l}010-4189- \\
8004\end{array}$ \\
\hline s096 & $\mathrm{Na}$ Okja & $\begin{array}{l}\text { Song } \\
\text { Hanseon }\end{array}$ & $\begin{array}{l}010-4646- \\
1831\end{array}$ \\
\hline
\end{tabular}




\subsection{Nearby Police Stations Closest to the Real-Time Location of the Dementia}

$<$ SQL execute statement>

SELECT DISTINCT TOP 5 PO_NAME,
PO_PNUM, ROUND (SQRT((s.S_LONG-
p.PO_LONG)*(s.S_LONG-
p.PO_LONG)+(s.S_LAT-
p.PO_LAT $)^{*}($ s.S_LAT-p.PO_LAT $\left.\left.)\right), \quad 7\right) \quad$ as
'DISTANCE'
FROM POLICE p, SENIOR s
WHERE S_ID='s080' ORDER BY 'DISTANCE'
ASC;

The tables used in this query are POLICE and SENIOR tables.

For drones to reach the senior quickly, drones from the police station close to the senior's real-time location must be called in. Therefore, information is needed about the police station closest to the senior's real-time position.

Under these conditions, the location of one particular senior is required, so the location distance between the senior and the police station is randomly designated as an senior with a S_ID of s080 and the distance between the location of the senior and that of the police station is arranged in an ascending order so that they can be identified in the order of the distance. The S_ID will be implemented later by receiving the S_ID of each senior.

The SELECT statement identifies the distance between the location of the senior and that of the police station. It has been created using a distance formula between two points.

$$
\overline{A B}=\sqrt{\left(x_{2}-x_{1}\right)^{2}+\left(y_{2}-y_{1}\right)^{2}}
$$

From the real-time longitude (S_LONG) of the senior $x_{2}$, the longitude (PO_LONG) of the police station $x_{1}$ was subtracted and squared. From the realtime latitude (S_LAT) of the senior $y_{2}$, the latitude (PO_LAT) of the police station $y_{1}$ was subtracted and then equally squared. The actual distance difference can be obtained by rooting the two values through the SQRT() function. TOP 5 prints out the five police stations with the least difference. The reason for printing out five police stations is to contact the nearest police station first, and then, if all the drones from that station have been sent out, the next one from the nearest police station.

Through the query, the police station close to the location of the senior can be identified, quickly and in an orderly manner, and a protector can be directed to a nearby police station so that the protector can mobilize the drones.

Table 3.Results of the Nearby Police Stations to the Dementia

\begin{tabular}{|lll|}
\hline PO_NAME & PO_PNUM & DISTANCE \\
\hline $\begin{array}{l}\text { Hwa Gok3 police } \\
\text { substation }\end{array}$ & $\begin{array}{l}02-2604- \\
2133\end{array}$ & 0.0003282 \\
\hline $\begin{array}{l}\text { Kkachisan Patrol } \\
\text { Division }\end{array}$ & $\begin{array}{l}02-2604- \\
5053\end{array}$ & 0.0183328 \\
\hline Ga Yang Patrol Division & $\begin{array}{l}02-3665- \\
9112\end{array}$ & 0.021086 \\
\hline Yeom Chang Patrol & $02-3665-$ & 0.0331398 \\
Division & 0660 & 0.0498018 \\
\hline $\begin{array}{l}\text { Gae Hwa Community } \\
\text { Security Center }\end{array}$ & $02-2661-$ & 0336 \\
\hline
\end{tabular}

The results of the above query are shown in Table 3.

4.4 Drones in the Police Station of Automatic Move for the DangerousDementia

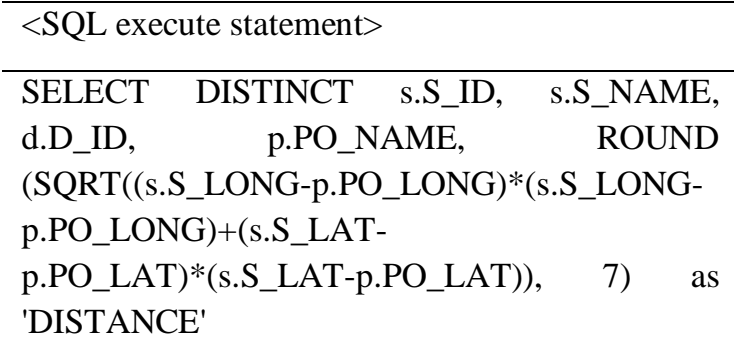

FROM SENIOR s, CAUTION c, POLICE p, DRONE d

WHERE s.S_LONG BETWEEN(c.C_LONG)0.002 and (c.C_LONG)+0.002 and s.S_LAT BETWEEN(c.C_LAT)-0.002 and (c.C_LAT) +0.002 and d.PO_ID=p.PO_ID ORDER BY 'DISTANCE' ASC;

The tables used in this query are the SENIOR, CAUTION, POLICE, and DRONE tables.

Not only the protectoris notified when the dementia senior enter a hazard zone, but a drone should 
Volume 8 Issue 7 July 2020

automatically move to him/her. Therefore, the conditions set the same hazard zone as in 3.2, and list all drones belonging to the police station in the order of distance difference from the hazard. It is assumed that each police station contains five drones. When the service is developed in the future, it canoutput only drones that can be mobilized.

The results of the above query are shown in Table 4 .

Table 4.Results of the Drones for the Dangerous Dementia

\begin{tabular}{|c|c|c|c|c|}
\hline $\begin{array}{l}\text { S_I } \\
\text { D }\end{array}$ & S_NAME & $\begin{array}{l}\text { D_I } \\
\text { D }\end{array}$ & $\begin{array}{l}\text { PO_NAM } \\
\text { E }\end{array}$ & $\begin{array}{l}\text { DISTANC } \\
\text { E }\end{array}$ \\
\hline s079 & $\begin{array}{l}\text { BaekJeong } \\
\text { su }\end{array}$ & d06 & $\begin{array}{l}\text { Hwa } \\
\text { Gok3 } \\
\text { police } \\
\text { substation }\end{array}$ & 0.0005614 \\
\hline s079 & $\begin{array}{l}\text { BaekJeong } \\
\text { su }\end{array}$ & $\mathrm{d} 07$ & $\begin{array}{l}\text { Hwa } \\
\text { Gok3 } \\
\text { police } \\
\text { substation }\end{array}$ & 0.0005614 \\
\hline s079 & $\begin{array}{l}\text { BaekJeong } \\
\mathrm{su}\end{array}$ & $\mathrm{d} 08$ & $\begin{array}{l}\text { Hwa } \\
\text { Gok3 } \\
\text { police } \\
\text { substation }\end{array}$ & 0.0005614 \\
\hline s079 & $\begin{array}{l}\text { BaekJeong } \\
\text { su }\end{array}$ & d09 & $\begin{array}{l}\text { Hwa } \\
\text { Gok3 } \\
\text { police } \\
\text { substation }\end{array}$ & \\
\hline s079 & $\begin{array}{l}\text { BaekJeong } \\
\text { su }\end{array}$ & $\mathrm{d} 10$ & $\begin{array}{l}\text { Hwa } \\
\text { Gok3 } \\
\text { police } \\
\text { substation }\end{array}$ & 0.0005614 \\
\hline s078 & BaekSunja & d06 & $\begin{array}{l}\text { Hwa } \\
\text { Gok3 } \\
\text { police } \\
\text { substation }\end{array}$ & 0.000749 \\
\hline s078 & BaekSunja & $\mathrm{d} 07$ & $\begin{array}{l}\text { Hwa } \\
\text { Gok3 } \\
\text { police } \\
\text { substation }\end{array}$ & 0.000749 \\
\hline s078 & BaekSunja & $\mathrm{d} 08$ & $\begin{array}{l}\text { Hwa } \\
\text { Gok3 } \\
\text { police } \\
\text { substation }\end{array}$ & 0.000749 \\
\hline s078 & BaekSunja & d09 & $\begin{array}{l}\text { Hwa } \\
\text { Gok3 } \\
\text { police } \\
\text { substation }\end{array}$ & 0.000749 \\
\hline s078 & BaekSunja & $\mathrm{d} 10$ & $\begin{array}{l}\text { Hwa } \\
\text { Gok3 } \\
\text { police } \\
\text { substation }\end{array}$ & 0.000749 \\
\hline s096 & $\mathrm{Na} O k j a$ & $\mathrm{~d} 06$ & $\begin{array}{l}\text { Hwa } \\
\text { Gok3 }\end{array}$ & 0.0015474 \\
\hline
\end{tabular}

\begin{tabular}{|lllll|}
\hline & & police & \\
& & & \\
substation & \\
s096 Na Okja $\quad$ d07 & $\begin{array}{l}\text { Hwa } \\
\text { Gok3 } \\
\text { police } \\
\text { substation }\end{array}$ & 0.0015474 \\
& & & \\
\hline
\end{tabular}

\section{CONCLUSIONS}

\subsection{Overall Conclusion}

The paper proposes the drone functional safe welfare service system for the dementia seniors and their protectors utilizing drones and big data in Korea, which has entered an aged society at a rapid pace. To solve the problems of dementia seniors being exposed to danger and protectors with increased stress, it recommends that devices identify the realtime location of the dementia senior and the protectors and that the police station provide services that enable the drone to be dispatched and situationsharing if desired.

Data from the dementia seniors and theirprotectors, the location-based and camera performance of drones, situation-sharing and police-station are key elements for safe services, which is an important foundation for providing out services in conjunction with the application.

The secure service for the dementia seniors focuses on the ability to prevent the seniors from being at risk and the provision of services tailored to their protectors needs.

By utilizing drones in the appearance of new innovative services and devices, we can live in a safer and more convenient life. Drone experts predict that drones will be used in many areas, including personal products, within 10 years. Futurologist Thomas Freypredicts drones as one of the seven emerging industries [19].

According to a survey by the Korean Society for Dementia, protectors for the dementia seniors feel pressured by the decrease in social life caused by nursing care, which leads to a surge in stress. This research has been initiated to increase the utility value of drones by providing safe out-of-the-box services for dementia seniors, to reduce the stress of theirprotector, and to stabilize the civil service at the police station.Based on the statistics of police stations and the data of senior citizens in Seoul Metropolitan Area, it automatically analyzes the 
Volume 8 Issue 7 July 2020

possibility of drones appearing when the senior is out and comes within the danger zone radius.

\subsection{Contributions}

The expected contributions by implementing the research are as follows.

First, the service system will contribute to reducing the missing probability of a dementia senior when they are going out without protection from their protectors.

Second, the service systemcan reduce the stress of protectorsof dementia seniors. Currently, the dementia senior is usually cared by a protector who is a member of the family claiming to be a protector or by hiring a protector. When real family members start nursing, the protectorstress increases due to a decrease in social lifetime. Conversely, even if protectors are employed or dementia seniorsare hospitalized in nursing homes, the same result is achieved by an increase in the economic burden. However, by introducing drones, protectors will be able to identify the real-time location of dementiaseniors, enabling them to focus on their social work and leisure.

Third,to protect various social underdogs beyond dementia seniors, it can increase the performance efficiency of the police administration.

In the past four years of Korea, a total of 458,369 people has been reported missing from their homes with dementia, children, intellectual disabilities and adult runaways. Also, 4,654 people have been reported missing but have yet to be found, with 116 cases for the intellectually disabled and 24 cases for the dementiaseniors. The social underdogs are often shivering with cold, fear and strange moods when they go missing. Introducing a system to watch whether these socially disadvantaged people return home safely while going out freely will not suppress their freedom of going out and allow them to recognize any mishaps in advance, making it easier to deal with.

Fourth, by a national institution, in 17 years Korea will become an aged society with more than 14 percent of the population aged 65 or older [20]. This suggests that the nation is on the verge of entering a super-aged society at a rapid pace, meaning that the nation should prepare a robust welfare security system for the seniorfrom now on. According to a survey on dementia epidemiology, one out of 10 seniorsin 2018 are dementiaseniors, and by 2050, one out of six seniorscould become dementiaseniors. Through the actual introduction of the "Dementia senior prowl sensor" the number of missing persons reports has decreased from 225 in 2015 to 187 in 2017 [21].

Fifth, if the service is stable it may expand the scope of the target and provide safety services to socially disadvantaged people such as children, the seniors and the disabled, which will increase the overall effectiveness of the safety of the Republic of Korea.

If the system provides real-time sharing of the situation using drones, it will further reduce reports of missing persons and increase the credibility of the national flag organs.

\subsection{Limitations}

Limitations of the research are as follows.

First, the technical limitations of the drones should be complemented. For commercial purposes, the flight time is only 15 to 20 minutes, and for commercial products, the flight distance is about 50 kilometers. Advance in battery technology that can fly for longer periods of time is essential. Also, the technology to prepare for a crash caused by a collision between drones and faulty gases should be complemented.

Second, government-level regulations are a challenge to overcome. Not only do they look at drones from country to country, but they also have different regulations and systems. In the case of Korea, five laws are regulated: The Aviation Act, the Propaganda Act and the Road Act. In line with the era of the fourth industrial revolution, drop-related regulations and systems should also be improved and supplemented to suit the times. In order to use drones in the private sector, the current aviation law or the radio wave law needs to be revised.

\section{ACKNOWLEDGEMENTS}

This work was supported by Hankuk University of Foreign Studies Research Fund of 2019.

\section{REFERENCES}

[1]National Health Information Portal, Medical Information

[2]An incurable disease 'Dementia'http://www.iloveorganic.co.kr/news/a rticleView.html?idxno=229858 
[3]"The dementia grandmother left home alone at 1 a.m. when the family was sleeping."https://m.insight.co.kr/news/255361

[4]Central Treatment Center

[5]Kyung Pil Kung, The State of Dementia Management and the National Dementia Responsibility System in Korea, report, 2018.

[6]Korean Society for the Dementia

[7]KT Sets Up Safety Control System Using Drone in Hwasung Cityhttp://m.joseilbo.com/news/view.htm?newsi $\mathrm{d}=350453$ \#_enliple

[8]A dark night road...The drone is a light.http://www.techholic.co.kr/news/articleVie w.html?idxno=63764

[9] E. Demir, E. Köseoğlu, R. Sokullu, and B.Şeker, "Smart home assistant for ambient assisted living of elderly people with dementia," International Workshop on IoT, M2M and Healthcare, Lund, pp. 609-614, 2017.

[10] Sex offender notification, http://www.sexoffender.go.kr

[11] "Flying your drone safely and legally Transport Canada", Tc.gc.ca, 2018. [Online]. Available:

https://www.tc.gc.ca/eng/civilaviation/opssvs/fly ing-drone-safelylegally.html.

[12]Hyun-ho Yang, A Study on the Organizational Management of the Security Drone Patrol, 2018.

[13] Radosveta Sokullu, Abdullah Balcı, and Eren Demir, "The role of Drones in ambient assisted living systems for the elderly," Enhanced Living Environments: Algorithms, Architectures, Platforms, and Systems, LNCS 11369,pp. 295321, Jan. 2019.

[14] S. J. Kim, G. J. Lim, J. Cho, and M. J. Cote, "Drone-aided healthcare services for patients with chronic diseases in rural areas," Journal of Intelligent \& Robotic Systems, vol. 88, pp. 163180, 2017.

[15] Saif Saad Fakhrulddin, Sadik Kamel Gharghan, Ali Al-Naji, and Javaan Chahl, "An advanced first aid system based on an unmanned aerial vehicles and a wireless body area sensor network for elderly persons in outdoor environments," Sensors, vol. 18, no. 13 : 2955, Jul.2019.
[16] G. Cipriani, C. Lucetti, A. Nuti and S. Danti, "Wandering and dementia", Psychogeriatrics, vol. 14, no. 2, pp. 135-142, 2014.

[17]TAAS Traffic Accident Analysis System. http://taas.koroad.or.kr/

[18]Seoul Metropolitan Police Center Information Center, Seoul Open Data Plaza

[19]The Fourth Industrial Revolution, as futurist Thomas Frey calls it. https://it.donga.com/27137/

[20]The shadow of aging...1 in 10 people over 65 years of age with dementia. https://www.mk.co.kr/news/it/view/2018/12/811 $811 /$

[21] Dementia senior prowl sensorhttps://blog.naver.com/qkrhj1004/221662 034613

\section{P}

